\title{
IMMUNITY OF SUGARCANE CULTIVARS TO Meloidogyne enterolobii
}

\author{
IMUNIDADE DE CULTIVARES DE CANA-DE-AÇÚCAR À Meloidogyne enterolobii
}

\author{
Gabriela Silva THOMAZELLI ${ }^{1}$; Roberta Luiza VIDAL ${ }^{1}$; Lúcio Roberto VIZENTINI ${ }^{1}$; \\ Daniel Dalvan do NASCIMENTO ${ }^{1}$; Renato Silva SOARES ${ }^{1}$; Alexandre Fameli MAMMANA ${ }^{1}$; \\ Rivanildo Júnior FERREIRA ${ }^{1}$; Pedro Luiz Martins SOARES ${ }^{1}$ \\ 1. Universidade Estadual Paulista "Júlio de Mesquisa Filho" - Faculdade de Ciências Agrárias e Veterinárias, Câmpus de Jaboticabal, \\ Departamento de Ciências da Produção Agrícola, Laboratório de Nematologia, Jaboticabal, SP, Brasil. pedrolms@fcav.unesp.br.
}

\begin{abstract}
Brazil is currently the world's largest producer and exporter of sugarcane, and the crop has high socioeconomic importance in the country. Root-knot nematodes (Meloidogyne spp.) are one of the major limiting factors in sugarcane production. These plant parasites have wide geographic distribution, high damage potential, and are difficult to control. Recently, the species Meloidogyne enterolobii was identified in sugarcane crops in the state of Pernambuco, Brazil. Given the importance of genetic resistance for integrated nematode management and the lack of research on the $M$. enterolobii-sugarcane pathosystem, this study aimed to assess the response of sugarcane cultivars to $M$. enterolobii. Thirteen cultivars were evaluated for their resistance to $M$. enterolobii based on the nematode reproduction factor. The experiment was conducted in a greenhouse, in a completely randomized design, with 14 replicates. Pre-sprouted sugarcane seedlings were transplanted to $5 \mathrm{~L}$ pots, and each pot was considered an experimental unit. At 15 days after transplanting, the seedlings were inoculated with 5,000 eggs and second-stage juveniles of $M$. enterolobii. Tomato and okra plants were also inoculated to test the viability of the inoculum. At 240 days after inoculation, plant roots were processed and evaluated for nematode number. This parameter was used to calculate the nematode reproduction factor on each cultivar. All sugarcane cultivars were found to be immune to M. enterolobii, with a reproduction factor of 0 .
\end{abstract}

KEYWORDS: Non-host culture. Root-knot nematode. Resistance. Reproduction factor. Saccharum spp.

\section{INTRODUCTION}

Sugarcane (Saccharum spp.) has great socioeconomic importance in Brazil. According to the Brazilian National Food Supply Company (CONAB, 2018), in the 2017/18 crop season, sugarcane crops occupied an area of 8.73 million hectares and produced about 633.3 million tonnes of sugarcane. The $2018 / 19$ production is estimated to reach 635.6 million tonnes. As a result of its high production capacity, Brazil is not only the world's largest producer of sugarcane and sugarcane products but also the largest exporter (FAO, 2018).

Sugarcane is affected by many biotic and abiotic yield-limiting factors that vary according to production region. With widespread occurrence, plant-parasitic nematodes are one of the major biotic factors affecting sugarcane and other agricultural crops. According to Dinardo-Miranda (2005), plantparasitic nematodes affect sugarcane yields on a national scale and crop losses reach up to $50 \%$ when nematode population levels are high.

Root-knot nematodes (Meloidogyne spp.) are among the most damaging pathogens parasitizing sugarcane. Meloidogyne incognita and
M. javanica are the two most common species (DIAS-ARIEIRA et al., 2010). Infected roots can be easily identified by the presence of galls, thick root tips, short primary root lengths, and absence of secondary roots. Symptomatic foci are commonly observed in nematode-infested fields, characterized by chlorotic, stunted, and, depending on infection intensity and cultivar, decayed plants (CHAVES et al., 2007). As root-knot nematodes reside in the soil but cause above-ground symptoms that resemble nutritional or water deficiency, farmers tend to identify the presence of these parasites when the infestation level is high and crop production has been impacted. Late diagnosis is even more troublesome in the case of sugarcane crops, which are semi-perennial and necessitate control before planting.

Moura et al. (2009) identified for the first time the presence of $M$. enterolobii (syn. $M$. mayaguensis) parasitizing sugarcane in the state of Pernambuco, Brazil. This root-knot nematode has gained notoriety in Brazil for the damage caused to guava and is currently considered the major pathogen of the crop (GOMES et al., 2010). According to Pereira et al. (2009), M. enterolobii 
caused a loss of $\mathrm{R} \$ 112.7$ million in 2008 , which resulted in 3,703 workers losing their jobs. When agricultural fields are highly infested by the nematode, it is recommended to replace guava for a non-host crop, as currently available nematode management strategies are economically unfeasible (GOMES et al., 2010).

Nematode management should integrate chemical, biological, and cultural control tactics. However, some of these methods have proved to be unsatisfactory (FULLER; LILLEY; URWIN, 2008). According to Silva et al. (2016), the control of nematodes in sugarcane fields is carried out using chemical nematicides; however, nematode populations can quickly surpass the threshold of economic damage after treatment, in about 90 to 120 days following application. Furthermore, chemical agents are highly harmful to the environment. $M$. enterolobii is polyphagous and can parasitize crops commonly used in rotation with sugarcane, such as corn and soybean (DIAS et al., 2010), as well as green manure species (ROSA; WESTERICH; WILCKEN, 2015). Thus, genetic resistance is considered one of the main pillars of nematode management (KHALLOUK et al., 2011; SILVA et al., 2016).

Trudgill (1991) defined genetic resistance as the ability of plants to inhibit nematode reproduction. The use of resistant plants can reduce nematode populations in infested sites to numbers below the threshold of economic damage. The only study assessing the resistance of sugarcane to $M$. enterolobii was that of Silva et al. (2012). The authors evaluated four sugarcane cultivars and found that three were resistant and one was immune to the nematode. The present study aimed to investigate the resistance of 13 sugarcane cultivars to M. enterolobii.

\section{CONTENTS}

The experiment was carried out from May 2017 to January 2018 in a greenhouse. Thirteen sugarcane (Saccharum spp.) cultivars were evaluated for their resistance to $M$. enterolobii, namely RB966928, RB867515, CTC4, RB92579, RB855156, RB855453, SP83-2847, RB975201, RB965902, RB975033, SP81-3250, RB985517, and RB975242. According to a sugarcane variety census conducted by the Interuniversity Network for the Development of the Sugarcane Industry (RIDESA, 2018 ), these cultivars accounted for $69 \%$ of the cultivated area and $65 \%$ of the planted area in the Central-Western, Northeastern, Southeastern, and
Southern regions of the country in the 2017/18 season.

A completely randomized design was used, with 14 replicates. Each plot (experimental unit) consisted of a $5 \mathrm{~L}$ pot containing one plant. Two nematode-susceptible controls, 'Santa Cruz 47' okra and 'Santa Cruz Kada' tomato, were used to validate inoculum viability and the suitability of environmental conditions for nematode development, also with 14 replicates each.

Pre-sprouted sugarcane seedlings were obtained from a commercial nursery and transplanted at 6 months of age to pots filled with a 1:3 mixture of soil and sand. The potting substrate $(910 \mathrm{~L})$ was previously autoclaved at $120{ }^{\circ} \mathrm{C}$ and 1 atm for 90 min and fertilized with $10.92 \mathrm{~kg}$ of 20-420 NPK fertilizer.

At 2 weeks after transplanting, seedlings were inoculated with $5 \mathrm{~mL}$ of a suspension containing 5,000 eggs and second-stage juveniles of $M$. enterolobii. The nematode inoculum was extracted from guava plants belonging to a nematode collection. Species confirmation was performed on the basis of morphological characteristics of the perineal (TAYLOR; NETSCHER, 1974) and labial regions of males (EISENBACK; HIRSCHMANN, 1981) and isoenzymatic phenotype for esterase (ESBENSHADE; TRIANTAPHYLLOU, 1990).

Broadcast fertilizer application was performed at 60 and 120 days after transplanting. Pest and disease management was performed as needed, without the use of nematicidal products. Irrigation was provided by a sprinkler system.

Nematodes were extracted from sugarcane roots at 8 months after inoculation. The roots were collected, carefully washed, and processed according to the method of Hussey and Baker (1973). Tomato and okra plants were subjected to the same procedures at 5 months of age, as they were entering senescence. The total number of eggs and second-stage juveniles was determined using a Peters' counting slide under a photonic force microscope and used to calculate the nematode reproduction factor (RF), as shown in Eq. (1):

$$
\mathrm{RF}=P_{\mathrm{f}} / P_{\mathrm{i}}
$$

where $P_{\mathrm{f}}$ is the final number of eggs and secondstage juveniles and $P_{\mathrm{i}}$ is the initial inoculum size $(5,000)$.

Cultivars were categorized into resistant $(R F<1)$, susceptible $(R F \geq 1)$, or immune $(R F=0)$ according to Oostenbrink (1996). 
All evaluated sugarcane cultivars were immune to $M$. enterolobii, with an RF of 0 (Table 1). Both susceptible controls (okra and tomato) had an $\mathrm{RF}>1$, showing that the inoculum was viable and environmental conditions were favorable to nematode multiplication. It should be noted that the $\mathrm{RF}$ values of nematodes on the controls were low, as nematode analysis was performed after 5 months of inoculation. The high susceptibility of tomato and okra plants to the nematode, added to the long infection period, resulted in a considerable loss of plant root system and, consequently, a reduction in nematode population numbers because of the lack of food.

Table 1. Mean total number of Meloidogyne enterolobii eggs and second-stage juveniles (TNEJ), reproduction factor (RF), and response (R) of sugarcane cultivars and two susceptible controls to the nematode.

\begin{tabular}{llll}
\hline Cultivars & TNEJ & RF & $\mathbf{R}^{(\mathbf{1})}$ \\
\hline RB966928 & 0 & 0 & $\mathrm{I}$ \\
RB867515 & 0 & 0 & $\mathrm{I}$ \\
CTC4 & 0 & 0 & $\mathrm{I}$ \\
RB92579 & 0 & 0 & $\mathrm{I}$ \\
RB855156 & 0 & 0 & $\mathrm{I}$ \\
RB855453 & 0 & 0 & $\mathrm{I}$ \\
SP83-2847 & 0 & 0 & $\mathrm{I}$ \\
RB975201 & 0 & 0 & $\mathrm{I}$ \\
RB965902 & 0 & 0 & $\mathrm{I}$ \\
RB975033 & 0 & 0 & $\mathrm{I}$ \\
SP81-3250 & 0 & 0 & $\mathrm{I}$ \\
RB985517 & 0 & 0 & $\mathrm{I}$ \\
RB975242 & 0 & 0 & $\mathrm{I}$ \\
'Santa Cruz Kada' tomato & 17,472 & 3.5 & $\mathrm{~S}$ \\
'Santa Cruz 47' okra & 12,960 & 2.6 & $\mathrm{~S}$ \\
\hline
\end{tabular}

${ }^{(1)}$ I, immune; S, susceptible.

Silva et al. (2012) evaluated sugarcane cvs. RB92579, RB863129, RB867515, and SP81-3250 inoculated with $0,5,000,10,000$, and 20,000 eggs and juveniles of $M$. enterolobii at 90 days postinoculation. The authors found that RB92579 was immune, whereas RB863129, RB867515, and SP813250 were resistant $(0<\mathrm{RF}<1)$. However, as highlighted by the authors, these results can be attributed to the response of each cultivar to nematodes and to the evaluation period. It may be necessary to extend the time between inoculation and evaluation. In the present study, the evaluation period was much longer (240 days) and was probably associated with the observed immunity in cultivars. As found by Niño, Arbeláez and Navarro (2008), the time of plant exposure to nematodes directly influences plant responses to the pathogen. The authors found no differences in stem diameter and shoot dry weight between uninoculated controls and plants inoculated with root-knot nematodes.

M. enterolobii is highly polyphagous and capable of parasitizing plants that are resistant to other Meloidogyne species (BITENCOURT; SILVA, 2010). The species is one of the major obstacles in guava production in Brazil (GOMES et al., 2010). The first reports of substantial damage to guava crops were made by Carneiro et al. (2001) in
Petrolina, Pernambuco, and Curaçá and Maniçoba, Bahia. Since then, the nematode has been detected in several guava-producing states. According to Reis et al. (2011), M. enterolobii can infest the entire root system of guava, from the radicle to the lignified vascular bundles, and cause secondary symptoms, such as strong darkening of the leaves and branches, followed by yellowing of the shoots, and, ultimately, total defoliation and death. $M$. enterolobii was responsible for damaging about 5,000 ha of guava in several Brazilian states, leading to an economic loss of R\$112.7 million (PEREIRA et al., 2009). Because of the severity of infection and high infestation rates, nematode control becomes nearly impossible, and crop replacement is recommended (GOMES et al., 2010). The nematode was recently identified as the cause of crop damage in India (POORNIMA et al., 2016).

The results of the current study show that sugarcane cvs. RB966928, RB867515, CTC4, RB92579, RB855156, RB855453, SP83-2847, RB975201, RB965902, RB975033, SP81-3250, RB985517, and RB975242 can be planted in $M$. enterolobii-infested sites, temporarily or not, because of their immunity to the root-knot nematode. Farmers can profit from sugarcane yields while reducing nematode populations in the area. 
Immunity of sugarcane...

\section{ACKNOWLEDGEMENTS}

Part of financial support by the Coordenação de Aperfeiçoamento de Pessoal de
THOMAZELLI, G. S. etal.

Nível Superior (CAPES) - Brazil - Finance Code 001.

RESUMO: O Brasil é atualmente o maior produtor e exportador mundial de cana-de-açúcar, tendo a cultura grande impacto socioeconômico no país. Dentre os diversos fatores que podem afetar sua produção se destacam os nematoides de galha (Meloidogyne spp.), por apresentarem ampla distribuição geográfica, alto potencial danoso e difícil controle. Recentemente a espécie Meloidogyne enterolobii foi identificada parasitando a cultura da cana-de-açúcar em Pernambuco. Dada à importância da resistência genética no manejo integrado de fitonematoides e a falta de trabalhos envolvendo o estudo desta espécie na cultura, o presente trabalho teve como objetivo avaliar a resposta de cultivares de cana-de-açúcar a $M$. enterolobii. Foram avaliadas 13 cultivares quanto a sua resistência a esta espécie com base no fator de reprodução do nematoide. $\mathrm{O}$ experimento foi conduzido em delineamento inteiramente casualizado, com 14 repetições, e mantido em casa de vegetação. Foram utilizadas mudas pré-brotadas de cana-de-açúcar, transplantadas para vasos de 5L, sendo cada vaso considerado uma unidade experimental. Cada unidade experimental foi inoculada com 5.000 ovos e juvenis de segundo estádio de $M$. enterolobii 15 dias após os transplantio. Plantas de tomateiro e quiabeiro também foram inoculadas para atestar a viabilidade do inoculo utilizado no experimento. Decorridos 240 dias da inoculação as raízes foram processadas para obtenção da população final e cálculo do fator de reprodução do nematoide de cada tratamento. Todas as cultivares de cana-de-açúcar avaliadas foram resistentes/imunes à $M$, enterolobii, apresentando fator de reprodução igual a zero.

PALAVRAS-CHAVE: Cultura não-hospedeira. Fator de reprodução. Nematoide de galha. Resistência. Saccharum spp.

\section{REFERENCES}

BITENCOURT, N. V.; SILVA, G. S. Reprodução de Meloidogyne enterolobii em olerícolas. Nematologia Brasileira, v. 34, n. 3, p. 181-183, 2010.

CARNEIRO, R. M. D. G.; MOREIRA, W. A.; ALMEIDA, M. R. A.; GOMES, A. C. M. M. Primeiro registro de Meloidogyne mayaguensis em goiabeira no Brasil. Nematologia Brasileira, v.25, n.2, p.223-228, 2001.

CHAVES, A.; MELO L. J. O. T.; SIMÕES, D. E. N.; COSTA, I. G.; PEDROSA, E. M. R. Declínio Severo do Desenvolvimento da Cana-de-Açúcar em Tabuleiros Costeiros do Estado de Pernambuco. Nematologia Brasileira, v.31, n. 2, p.93-95, 2007.

COMPANHIA NACIONAL DE ABASTECIMENTO - CONAB. Série histórica das safras: Cana-de-açúcar Indústria. Available in: <https://www.conab.gov.br/info-agro/safras/serie-historica-das-safras $>$. Accessed Dezember 22, 2018.

DIAS, W. P.; FREITAS, V. M.; RIBEIRO, N. R.; MOITA, A. W.; HOMECHINS, M.; PARPINELLI, N. M. B.; CARNEIRO, R. M. D. G. Reação de Genótipos de Soja a Meloidogyne enterolobii e M. ethiopica.

Nematologia Brasileira, v. 34, n. 4, p. 220-225, 2010.

DIAS-ARIEIRA, C. R.; SANTOS, D. A.; SOUTO, E. R.; BIELA, F.; CHIAMOLERA, F. M.; CUNHA, T. P. L.; SANTANA, S. M.; PUERARI, H. H. Reação de variedades de cana-de-açúcar aos nematoides-das-galhas. Nematologia Brasileira, v. 34, n. 4, 2010.

DINARDO-MIRANDA, L. L. Nematoides e pragas de solo em cana-de-açúcar. Encarte de Informações Agronômicas, v. 110, n. 1, p. 25-32, 2005. 
EISENBACK, J. D.; HIRSCHMANN, H. Identification of Meloidogyne Species on the basis of head shape and, stylet morphology of the male. Journal of Nematology, v.4, n.13, p.513, 1981.

ESBENSHADE, P. R.; TRIANTAPHYLLOU, A. C. Isozyme phenotypes for the identification of Meloidogyne species. Journal of nematology, v.1, n.22, p.10, 1990.

FOOD AND AGRICULTURE ORGANIZATION - FAO. Faostat. Available in: http://www.fao.org/faostat/en/\#data/QC>. Accessed Dezember 22, 2018.

FULLER, V. L.; LILLEY, C. J.; URWIN, P. E. Nematode resistance. New Phytologist, v. 180, p. 27-44, 2008. https://doi.org/10.1111/j.1469-8137.2008.02508.x

GOMES, V. M.; DOLINSKI, C.; CORREAA, F. M.; SOUZA, R. M. Management of Meloidogyne mayaguensis in commercial guava orchards with chemical fertilization and organic amendments. Nematologia Brasileira, $v$. 34, n. 1, p. 23-30, 2010.

HUSSEY, R. S.; BARKER, K. R. A comparison of methods of collecting inocula of Meloidogyne spp., incluinding a new technique. Plant Disease Reporter, v.57, n. 12, p. 1025-1028. 1973.

KHALLOUK, S.; VOISIN, R.; VAN GHELDER, C.; ENGLER, G.; AMIRI, S.; ESMENJAUD, D. Histological mechanisms of the resistance conferred by the Ma gene against Meloidogyne incognita in Prunus spp. Phytopathology, v.101, n.8, p.945-951, 2011. https://doi.org/10.1094/PHYTO-01-11-0004

MOURA, R. M.; ALMEIDA, R. M. A.; COSTA, M.; LIMA, S. T. S.; CARNEIRO, R. M. D. G. Meloidogyne species detected in sugarcane fields in the State of Pernambuco, Brazil. Nematologia Brasileira, v.33, n.4, p.329, 2009.

NIÑO, N. E.; ARBELÁEZ, G.; NAVARRO, R. Effect of different population densities of Meloidogyne hapla on the cape gooseberry (Physalis peruviana L.) in greenhouse. Agronomía Colombiana, v.26, n.1, p.5867, 2008.

OOSTENBRINK, M. Major characteristics of the relation between nematodes and plants. Mendelingen van de Landbouwhoge school te Wageningen, v.66, n. 4, p.1-46, 1966.

PEREIRA, F. O. M.; SOUZA, R. M.; SOUZA, P. M.; DOLINSKI, C.; SANTOS, G. K. Estimativa do impacto econômico e social de direto de Meloidogyne mayaguensis na cultura da goiaba no Brasil. Nematologia Brasileira, v. 33, n. 2, 2009.

POORNIMA, K.; SURESH, P.; KALAIARASAN, P.; SUBRAMANIAN, S.; RAMARAJU, K. Root knot nematode, Meloidogyne enterolobii in guava (Psidium guajava L.) a new record from India. Madras Agricultural Journal, v. 103, n. 1, p. 359- 365, 2016

REIS, H. F.; BACCHI, L. M. A.; VIEIRA, C. R. Y.; SILVA, V. S. Occurrence of Meloidogyne enterolobii (sin. M. mayaguensis) on guava in i in Ivinhema city, state of Mato Grosso do Sul, Brazil. Revista Brasileira de Fruticultura, v. 33, n. 2, p. 676-679, 2011. https://doi.org/10.1590/S0100-29452011000200042

RIDESA. Censo Varietal Brasil - 2017/18. Available in: <https://www.ridesa.com.br/censo-varietal> Accessed Dezember 22, 2018.

ROSA, J. M.; WESTERICH, J. N.; WILCKEN, S. R. S. Meloidogyne enterolobii reproduction on vegetable crops and plant used as green manure. Revista Ciência Agronômica, v. 46, n. 4, p. 826-835, 2015. https://doi.org/10.5935/1806-6690.20150071 
SILVA, A. P.; PEDROSA, E. M. R.; CHAVES, A.; MARANHÃO; S. R. V. L.; GUIMARÃES, L. M. P.; ROLIM, M. M. Reaction of sugarcane varietis to Meloidogyne incognita and M. enterolobii parasitism. Revista Brasileira de Ciências Agrárias, v. 7, n. 1, p. 814 - 819, 2012. https://doi.org/10.5039/agraria.v7isa2276

SILVA, M. S.; BANDEIRA, M. A.; MARANHÃO, S. R. V. L.; CARVALHO, R. M.; PEDROSA, E. M. R. Comportment of sugarcane genotypes RB to root-knot nematode parasitism. Revista Brasileira de Ciências Agrárias, v. 11, n. 2, p. 73-79, 2016. https://doi.org/10.5039/agraria.v11i2a5368

TAYLOR, D. P.; NETSCHER, C. An improved technique for preparing perineal patterns of Meloidogyne spp. Nematologica, v.2 n.20, p.268-269, 1974. https://doi.org/10.1163/187529274X00285

TRUDGILL, D. L. Resistance and tolerance of plant parasitic nematodes in plants. Annual Review of Phytopathology, v. 29, p. 167-192, 1991. https://doi.org/10.1146/annurev.py.29.090191.001123 